\title{
Experimental infection of the bat tick Carios fonsecai (Acari: Ixodidae) with the rabies virus
}

\author{
Silvana Regina Favoretto ${ }^{[1],[2], ~ M a r i l e n e ~ F e r n a n d e s ~ d e ~ A l m e i d a ~}{ }^{[3]}$, \\ Luzia Fátima Alves Martorelli ${ }^{[3]}$, Caroline Cotrin Aires ${ }^{[4]}$, Marcelo Bahia Labruna ${ }^{[5]}$, \\ Ana Paula Arruda Geraldes Kataoka ${ }^{[3]}$, Angélica Cristine de Almeida Campos ${ }^{[2]}$, \\ Débora Regina Veiga Sacramento ${ }^{[6]}$, Edison Luiz Durigon ${ }^{[2]}$ and Hilary Koprowski ${ }^{[7]}$
}

[1]. Instituto Pasteur de São Paulo, São Paulo, SP. [2]. Núcleo de Pesquisas em Raiva, Instituto de Ciências Biomédicas, Universidade de São Paulo, São Paulo, SP. [3]. Centro de Controle de Zoonoses, Prefeitura do Município de São Paulo, São Paulo, SP. [4]. Secretaria Municipal da Saúde, Supervisão de Vigilância em Saúde, São Paulo, São Paulo, SP. [5]. Faculdade de Medicina Veterinária, Universidade de São Paulo, São Paulo, SP. [6]. Genomic Engenharia Molecular Ltda, São Paulo, SP. [7]. Department of Cancer Biology, Jefferson Medical College, Thomas Jefferson University, PA, USA.

\begin{abstract}
Introduction: This study assessed the viability of the rabies virus in the argasid tick Carios fonsecai following experimental infection. Methods: The mouse inoculation test (MIT), fluorescent antibody test (FAT) and polymerase chain reaction (PCR) were used. The rabies virus was administered to ticks via the intra-coelomic route, and the ticks were sacrificed at different time points. Results: The inoculated ticks were negative for rabies according to the MIT. Ticks macerated with rabies virus were positive according to the MIT and FAT. All of the tick lots tested by PCR were positive. Conclusions: The rabies virus became unviable shortly after its inoculation into tick bodies. Ticks are not likely to play an important role in the epidemiology of rabies.
\end{abstract}

Keywords: Rabies. Bats. Ticks. Carios fonsecai.

Ticks belong to the order Acari, which is divided into the Ixodidae $(\approx 700$ species $)$, Argasidae $(\approx 200$ species $)$ and Nuttalliellidae (one species) families. Although a few species of Ixodidae have occasionally been reported to infest bats, approximately one-third of the Argasidae species have been observed to feed primarily on different bat species around the world ${ }^{1,2}$. All tick species are hematophagous during one or more phases of their life cycles. For this reason, these arthropods have been examined for their role as the vectors of different agents (viruses, bacteria, protozoa and helminths) that infect vertebrate hosts. In fact, it has been reported that a greater variety of agents are transmitted by ticks than by any other vector group, including mosquitoes ${ }^{1}$. In Brazil, certain argasid ticks (Carios spp.) that are associated with bats have been reported to infest humans, primarily under indoor conditions, as these ticks are maintained by bats that live in the roofs of human dwellings ${ }^{3,4}$.

Bats belong to the order Chiroptera and are present throughout almost the entire world. Bats comprise the mammalian group with the second-largest number of species; in particular, there are 1,120 species of bats. There are nine families, 64 genera and 167 species of bats that live in Brazil ${ }^{5}$.

\footnotetext{
Address to: Dra Silvana Regina Favoretto. Av. Lineu Prestes 1374/Sala 225, Cidade Universitária, 05508-900 São Paulo, SP, Brasil.

Phone: 55113091 7293; Fax: 551130917354

e-mail: srfavoretto@usp.br

Received 21 June 2012

Accepted 8 October 2012
}

According to antigenic and genetic characterization studies of rabies, bats are among the most important reservoirs and vectors of the rabies virus around the world ${ }^{6,7}$. In recent years, however, certain human rabies cases associated with bat variants have been detected in the absence of skin lesions that were attributable to bat bites and in cases that lacked any documented history of bat bites.

Based on this information, the present study sought to examine the viability of the rabies virus in an argasid tick species, despite ticks never having been observed to be infected naturally by rabies viruses.

The ticks used in this study were derived from a laboratory colony of Carios fonsecai (Acari: Argasidae) that was originally collected in April 2005 in the São Miguel cave in the State of Mato Grosso do Sul, which is in the central-western region of Brazil. Within this cave, the hematophagous bat Desmodus rotundus was observed to be a host of $C$. fonsecai under natural conditions ${ }^{4}$. The tick colony in question has been maintained in the laboratory. In that setting, naïve rabbits and/or mice have been used to feed the ticks. For the present study, nymphs and adult ticks of the $\mathrm{F}_{2}$ to $\mathrm{F}_{4}$ lab generations were utilized.

In this study, a fluorescent antibody test (FAT $)^{8}$ and a mouse inoculation test (MIT) ${ }^{9}$ were used to diagnose the presence of rabies. The genetic characterization was obtained by reverse transcriptase-polymerase chain reaction (RT-PCR), followed by deoxyribonucleic acid (DNA) sequencing ${ }^{10}$.

The rabies virus variant that was used in this study (Brldr2918) was isolated in 1997 from the brain of a D. rotundus bat. The first mouse passage of this bat isolate was preserved 
at $-70^{\circ} \mathrm{C}$ until it was used for the present study. The viral doses were previously tested in rabies studies by the vaccination and experimental infection of $D$. rotundus bats ${ }^{11}$, and the doses were standardized in the present study for the inoculation of ticks.

The rabies virus was administered $(0.03 \mathrm{~mL})$ to adult ticks or nymphs by an intra-coelomic route through the articulation of the coxa IV and trochanter IV of each tick (Figure 1), using a 28 -gauge microfine insulin needle, in accordance with previously described procedures ${ }^{12}$.

All of the ticks were inoculated with $10^{5.99}$ mouse intracerebral lethal doses $\left(\mathrm{MICLD}_{50}\right) / 0.03 \mathrm{~mL}$, except for the ticks tested at $0.5 \mathrm{~h}$ post-inoculation, which were inoculated with $10^{2.35} \mathrm{MICLD}_{50} / 0.03 \mathrm{~mL}$ (Table 1).

The inoculated ticks were maintained alive at room temperature until different time points (from $0.5 \mathrm{~h}$ to $48 \mathrm{~h}$ postinoculation), until they were assessed for the presence of rabies virus by RT-PCR and MIT. The FAT was conducted to confirm rabies in symptomatic mice.

The RT-PCR tests were performed using the rabies virus oligonucleotides 'SeqN' and '304', which generate a 765-bp

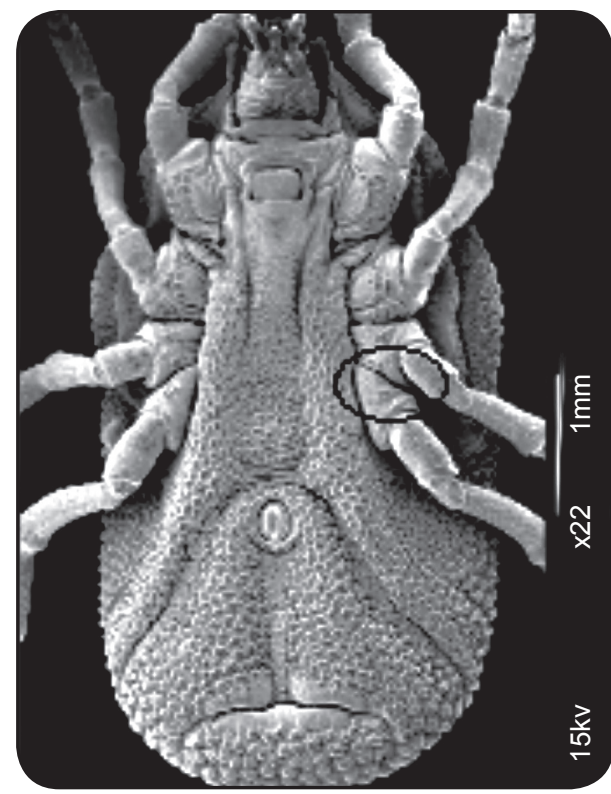

FIGURE 1 - Scanning electron microscopy of Carios fonsecai, ventral view: in the ellipse is the detail of the intra-coelomic route through the articulation of the coxa VI and trochanter IV, which is the region where the rabies virus was inoculated (Labruna \& Venzal, 2009 authorized).

TABLE 1 - The number of ticks (Carios fonsecai) inoculated with the rabies virus, according to the post-inoculation time at which they were killed for rabies diagnoses.

\begin{tabular}{|c|c|c|c|c|c|c|}
\hline \multirow[b]{3}{*}{ Hours post-inoculation } & \multirow{2}{*}{\multicolumn{2}{|c|}{ Number of ticks }} & \multicolumn{4}{|c|}{ Age } \\
\hline & & & \multicolumn{2}{|c|}{ nymphs } & \multicolumn{2}{|c|}{ Adults } \\
\hline & nymph & adult & MIT & PCR & MIT & PCR \\
\hline 0.5 & 0 & 6 & NP & NP & - & + \\
\hline 1 & 1 & 1 & - & + & - & + \\
\hline 2 & 1 & 1 & - & + & - & + \\
\hline 3 & 1 & 1 & - & + & - & + \\
\hline 4 & 1 & 1 & - & + & - & + \\
\hline 5 & 1 & 1 & - & + & - & + \\
\hline 8 & 1 & 1 & - & + & - & + \\
\hline 9 & 1 & 1 & - & + & - & + \\
\hline 12 & 1 & 1 & - & + & - & + \\
\hline 13 & 1 & 1 & - & + & - & + \\
\hline 17 & 1 & 1 & - & + & - & + \\
\hline 21 & 1 & 1 & - & + & - & + \\
\hline 24 & 2 & 2 & - & + & - & + \\
\hline 30 & 1 & 1 & - & + & - & + \\
\hline 36 & 1 & 1 & - & + & - & + \\
\hline 48 & 1 & 1 & - & + & - & + \\
\hline Inoculated total & 16 & 22 & & & & \\
\hline Macerated with rabies virus & 0 & 12 & NP & NP & + & + \\
\hline
\end{tabular}

MIT: mouse inoculation test; PCR: polymerase chain reaction; NP: not performed. 
amplified product of the nucleoprotein ${ }^{13}$. The PCR procedures were conducted in accordance with previously described methods ${ }^{14}$. Tick inoculations were always and immediately followed by MIT of the same inoculum and viral dose, to test the viability of the inocula used in the present study.

To verify any harmful effects of tick contents on virus viability, 12 adult ticks were macerated with $500 \mu \mathrm{L}$ of rabies virus and $300 \mu \mathrm{L}$ of phosphate buffer saline (PBS) (dose $10^{5.61}$ $\mathrm{MICLD}_{50} / 0.03 \mathrm{~mL}$ after dilution). The resulting homogenate and controls were tested by MIT and RT-PCR. As recommended for rabies diagnosis, the brains of symptomatic mice were submitted to FAT. The control samples consisted of the same viral dose, both with and without tick homogenate (Table 1).

The Ethics Committees of the University of São Paulo and of the Zoonosis Control Center authorized all of the experimental procedures described in this study.

All of the ticks that were inoculated with rabies virus and were tested by MIT at 0.5 to $48 \mathrm{~h}$ after inoculation were negative for the virus (Table 1). These results indicate that once deposited inside the tick body, the rabies virus became unviable as soon as $30 \mathrm{~min}$ after inoculation. In contrast, all of the mice (control) inoculated with the same virus inoculum were positive according to the MIT. Therefore, it is possible to infer that the rabies virus was unable to multiply in $C$. fonsecai tissues, resulting in its lack of infectivity after 30 min inside the tick body. However, the 12 tick homogenates derived from ticks macerated with the rabies virus were used to inoculate seven mice, and six of these mice died between six and 10 days after this inoculation. The brain samples of these six mice were positive for rabies by FAT. Thus, the rabies virus remained viable in the tick homogenates. All of the tick lots that were tested by PCR, from 0.5 to $48 \mathrm{~h}$ after inoculation, were positive for the presence of viral RNA, as were the tick homogenates macerated with the rabies virus and the inoculum control samples.

A previous study ${ }^{15}$ attempted to infect the argasid ticks Ornithodoros moubata and Ornithodoros parkeri by inoculating high titers of rabies virus directly into the tick coelom, similar to the method that was used in the present study. In contrast to our findings, Bell et al. ${ }^{15}$ reported that the rabies virus survived within inoculated ticks for up to 13 days after inoculation, according to the testing of tick homogenates by MIT. However, when different tick species, either Argasidae or Ixodidae, were exposed to infection through artificial feeding on a rabies virus-infected diet, they retained the virus for up to either three days (in ixodid ticks) or three weeks (in argasid ticks), although the ticks were not able to transmit the virus during their hematophagic interactions with susceptible hosts ${ }^{15}$.

None of the tick species evaluated by Bell et al. ${ }^{15}$ were observed to feed on bats under natural conditions. Thus, in the present study, we decided to evaluate the infectiveness of a bat virus isolate in the tick species $C$. fonsecai, which is a natural ectoparasite of bats (including D. rotundus) in a rabies-endemic area of Brazil. Despite these conditions, the results of this study corroborate the conclusion of Bell et al. ${ }^{15}$ and support the notion that argasid ticks are not likely to play an important role in the epidemiology of rabies.

\section{ACKNOWLEDGMENTS}

The authors thank Dr. Luiz Francisco Sanfilippo for his technical support during the tick collection process.

\section{CONFLICT OF INTEREST}

The authors declare that there is no conflict of interest.

\section{REFERENCES}

1. Hoogstraal H. Argasid and Nuttalliellid ticks as parasites and vectors. Adv Parasitol 1985; 24:135-238.

2. Guglielmone AA, Robbins RG, Apanaskevich DA, Petney TN, EstradaPena A, Horak IG, et al. The Argasidae, Ixodidae and Nuttalliellidae (Acari: Ixodida) of the world: A list of valid species names. Zootaxa 2010; 2528:1-28.

3. Carvalho JCM. Note on the association of the tick Ornithodoros talaje (Guérin-Meneville), with infestations in human dwellings in Brazil. J Parasitol 1942; 28:165.

4. Labruna MB; Venzal JM. Carios fonsecai sp. Nov. (Acari, Argasidae), a bat tick from the central-wetern region of Brazil. Acta Parasitologica. 2009; 54:355-363.

5. Sodré MM, Gama AR, Almeida MF. Updated List of bat species positive for rabies in Brazil. Rev Inst Med Trop S Paulo 2010; 52:75-81.

6. World Health Organization. WHO Expert Consultation on Rabies. WHO Technical Report Series 931. Geneva: WHO: 2005.[Cited 2011 november 3]Available from: who.int/entity/rabies/trs931 06 05.pdf Accessed in nov 03, 2011.

7. Albas A, Campos AC, Araujo DB, Rodrigues CS, Sodré MM, Durigon EL, et al. Molecular characterization of rabies virus isolated from nonhaematophagous bats in Brazil. Rev Soc Bras Med Trop 2011; 44: 678-683.

8. Dean DJ, Abelseth MK, Atanasiu P. The fluorescent antibody. In: Meslin F-X, Kaplan MM, Koprowski $\mathrm{H}$ editors Laboratory techniques in rabies. $4^{\text {th }}$ ed. World Health Organization. Genebra: 1996. p. 88-95.

9. Koprowski H. The mouse inoculation test. In: Meslin F-X, Kaplan MM, Koprowski H editors.Laboratory techniques in rabies. $4^{\text {th }}$ ed. World Health Organization. Genebra: 1996; p. 80-86.

10. Martorelli LFA, Aguiar EAC, Almeida MF, Durigon EL. Genetic characterization of rabies virus isolates from São Paulo State, Brazil, during the period 1989-2000. In: XII International Meeting on Research Advances and Rabies Control in the Americas. Peterborough, Canada. 2001; November, 12-16.

11. Almeida MF, Martorelli LFA, Aires CC, Sallum PC, Durigon EL, Massad E. Experimental rabies infection in hematophagous bats Desmodus rotundus. Epidemiol and Infect 2005; 133:523-527.

12. Sangioni LA, Horta MC, Vianna MCB, Gennari SM, Soares RM, Galvão MA, et al. Rickettsial infection in animals and Brazilian spotted fever endemicity. Emerg Infect Dis 2005; 11:265-270.

13. Campos AC, Melo FL, Romano CM, Araújo DB, Cunha EM, Sacramento DR, et al. One-step protocol for amplification of near full-length cDNA of the rabies virus genome. J Virol Methods 2011; 174:1-6.

14. Smith JS. Rabies virus. In: Murray PR, Baron EJ, Pfaller MA, Tenover FC, Yolken R. Manual of clinical microbiology. $6^{\text {th }}$ ed. American Society for Microbiology Press; Washington: 1995. p. 997-1003.

15. Bell JF, Burgdorfer, W, Moore, GJ. The behavior of rabies virus in ticks. J Infect Dis 1957; 100:278-283. 